\title{
Allometric estimation of the productivity of phytoplankton assemblages
}

\author{
I. R. Joint, A. J. Pomroy \\ Natural Environment Research Council, Plymouth Marine Laboratory, Prospect Place, The Hoe, Plymouth PL1 3DH, United \\ Kingdom
}

\begin{abstract}
An allometric model is used to estimate the productivity of natural phytoplankton assemblages. The ${ }^{14} \mathrm{C}$ fixation rates of $>5 \mu \mathrm{m}$ phytoplankton cells, measured over a 5 yr period in the Celtic Sea, are used to test the relationship between cell size and productivity of natural phytoplankton assemblages. Phytoplankton biomass, as estimated from cell volume, explains between 85 and $90 \%$ of the variance in ${ }^{14} \mathrm{C}$ fixation rate under optimum growth conditions; in comparison, chlorophyll a concentration explains only $59 \%$ of the variance. An allometric model, applied to the estimated. phytoplankton biomass, is used to calculate the potential productivity of the phytoplankton under optimum growth conditions; this estimate of phytoplankton productivity explains $93 \%$ of the variance in the in situ ${ }^{14} \mathrm{C}$ fixation rate. When applied to data obtained over a $4 \mathrm{~d}$ period in the Celtic Sea, differences are found in the growth rate of individual species as well as in presumed losses due to grazing and sedimentation. This approach has the potential to estimate the productivity of each of the individual phytoplankton species which comprise a natural assemblage.
\end{abstract}

\section{INTRODUCTION}

For $3 \frac{1 / 2}{2}$ decades since its introduction (Steeman Nielsen 1951), the photosynthetic assimilation of radiocarbon $\left({ }^{14} \mathrm{C}-\mathrm{CO}_{2}\right)$ tracer has been the standard method of estimating phytoplankton productivity. It has been criticised on many grounds, not least that it may grossly underestimate primary productivity (see review by Peterson 1980). However, in spite of these doubts, the method has continued to be used extensively because it offers a simple, precise and extremely sensitive method of estimating the productivity of very dilute suspensions of phytoplankton cells. Recent research is tending to dispel many of the doubts that have been expressed over the method's accuracy; comparisons with oxygen production measurements (Williams et al. 1983, Davies \& Williams 1984, Bender et al. 1987) suggest that the ${ }^{14} \mathrm{C}$ method estimates something between net and gross production. For many studies, it seems likely that ${ }^{74} \mathrm{C}$ incorporation will continue to be the method of choice in studies of phytoplankton productivity and that it will give a reasonable estimate of the natural assemblage under study.

However, the ${ }^{14} \mathrm{C}$ method can give no information on the individual phytoplankton cells that make up a natural assemblage. The ${ }^{14} \mathrm{C}$ productivity estimate approximates to a median value for the productivity of al] the organisms present. Many workers have attempted to circumvent these limitations by applying size fractionation techniques to the ${ }^{14} \mathrm{C}$ method. The approach has been successful, particularly in estimating the productivity of nanoplankton and picoplankton (Joint 1986). However, only minimal information has been extracted from ${ }^{14} \mathrm{C}$ estimates on the microphytoplankton that frequently dominate natural assemblages.

A parallel development in ecological research has concerned allometry, that is, the relationship between the size of an organism and some function of its metabolism such as respiration or growth rate. It is well known that the rates of metabolic processes of living organisms are inversely related to size and that sizedependence in the growth rate of micro-organisms can be described by an allometric relation.

$$
\text { rate }=\mathrm{a} W^{\mathrm{b}}
$$

where rate is growth rate or some other metabolic function; $W=$ a measure of the mass of the organism; and (a) and (b) are constants (Peters 1983). Fenchel (1974) was the first to demonstrate that this relationship applied to the growth rate of microbes up to the size of ciliates, and the concept has been extended by Banse 
(1976, 1982) to include unicellular algae. A second related area of ecological research has shown that the flow of energy can be better represented as a function of organism size than of the trophic level (Platt \& Denman 1977, 1978, Vézina 1986). Analysis of biomass spectra are providing new insights into the functioning of benthic (Schwinghamer 1981, Warwick 1984) and pelagic communities (Warwick et al. 1986, Warwick \& Joint 1987). Therefore, organism size is emerging as an important common feature of much current ecological research

We propose to test allometric theory using data obtained with natural phytoplankton assemblages and to use cell size to estimate the potential growth rate of individual phytoplankton. We considered that such an approach might now be a viable addition to the ${ }^{14} \mathrm{C}$ method since recent developments in image analysis technology have provided a simple procedure for measuring precisely the dimensions of algal cells

\section{METHODS}

${ }^{14} \mathrm{C}$ production estimation. Photosynthetic fixation of ${ }^{14} \mathrm{C}$ has been determined at a number of stations in the Celtic Sea; samples were incubated in situ for $24 \mathrm{~h}$ and fractionated through $5 \mu \mathrm{m} 1 \mu \mathrm{m}$ and $0.2 \mu \mathrm{m}$ pore-size Nuclepore filters, as part of a study of picophytoplankton production (Joint \& Pomroy 1983, 1986, Joint et al. 1986). In this paper, we use only the ${ }^{14} \mathrm{C}$ fixation rates for phytoplankton $>5 \mu \mathrm{m}$, i.e. that retained on the $5 \mu \mathrm{m}$ pore-size Nuclepore filter.

Phytoplankton cell counts. Aliquots of the water samples taken at sea for ${ }^{14} \mathrm{C}$ incubations were preserved with $1 \%$ Lugol's iodine or $2.5 \%$ electron-microscope grade glutaraldehyde. The Lugol's iodine samples were stored in the dark until analysed (always less than $3 \mathrm{mo}$ ) and glutaraldehyde samples were stored in the refrigerator for up to 2 mo before analysis. Organisms $<5 \mu \mathrm{m}$, principally bacteria and microflagellates, were counted by epifluorescence microscopy, using the fluorochrome DAPI, 4'6-diamidino-2phenylindole (Porter \& Feig 1980). Cell counts and identification of phytoplankton species $>5 \mu \mathrm{m}$ were done by standard techniques using an inverted microscope (Hasle 1978). Phytoplankton was identified using standard identification texts. Many of the flagellates and some of the dinoflagellates could not be identified to species or even to genus; however, they all had morphological features which were used to distinguish them. A total of 159 species were identified and counted in samples taken at Stn CS2 in the Celtic Sea between July 1982 and June 1986. Some species lists have been published; for example, the phytoplankton present in July 1985 can be found in Joint \& Pomroy (1986) and Warwick \& Joint (1987).

Phytoplankton biomass estimation using a microscope-based image analyser. Cell dimensions of representative samples of phytoplankton were measured with a Kontron IBAS image analysis system, linked to a Reichert Polyvar research microscope. Precise measurements of cell dimension are possible with this instrument and a total of 91 different species were analysed; between 50 and 100 individual cells were measured for the 15 most abundant species, but less than 5 individuals, and sometimes only one, were analysed for 40 of the rarer phytoplankton. Two parameters were measured, the maximum cell dimension $\left(D_{\max }\right)$, which may be the diagonal of a rectangular cell, and the area of the phytoplankton image; the latter is not the surface area of the cell but the projection area of the image. A geometric shape was assigned to each species; the shapes used were sphere, cylinder, cone, double cone, hemisphere + cone, elliptic disk, elliptic cylinder, ellipsoid of revolution and semi-ellipsoid of revolution. Smayda (1965) recommends that when diatoms with large vacuoles make a significant contribution to phytoplankton biomass, it is necessary to make a correction to the estimated cell volume because cytoplasm may occupy only a fraction of the cell volume; however this correction is inappropriate here as algae with vacuoles did not form a significant proportion of the biomass in our samples.

The volume of each cell measured was calculated from $D_{\max }$ and projection area and the estimates were summed to give a mean volume for each species and standard deviation. We do not list the shapes assigned here but a partial listing is given in Warwick \& Joint (1987) of the geometric shapes assigned to the phytoplankton present in July 1985 and the estimated volume $\left(\mu \mathrm{m}^{3}\right)$ and standard deviations.

Estimation of cell carbon content. The cell volume estimated for each individual cell (in $\mu \mathrm{m}^{3}$ ) was used to calculate the carbon content of each individual (in pg C cell ${ }^{-1}$ ) and the values were summed to give the mean carbon content for each species and standard deviation. Two sets of equations were used to calculate cellular carbon content, both of which treated diatoms separately from other phytoplankton. Firstly, the equations derived by Strathmann (1967) were:

Diatoms:

$\log _{10}$ carbon $=-0.422+0.758\left(\log _{10}\right.$ cell volume $)$

Others:

$\log _{10}$ carbon $=-0.460+0.866\left(\log _{10}\right.$ cell volume $)$

We refer to estimates of cell carbon content made with these equations as Method 1. Secondly, we used the modified parameters of Taguchi (1976) for diatoms 
and those of Eppley et al. (1970) for other phytoplankton:

Diatoms:

$\log _{10}$ carbon $=-0.580+0.740\left(\log _{10}\right.$ cell volume $)$

Others:

$\log _{10}$ carbon $=-0.600+0.940\left(\log _{10}\right.$ cell volume $)$

We refer to estimates made with these parameters as Method 2. The carbon content due to each species in a sample was calculated by multiplying the number of cells $1^{-1}$ (determined by microscopy) by the mean carbon content of the species.

Estimation of potential growth rate. Banse (1982) has collated data from the literature on the growth rates of common coastal and oceanic diatoms and dinoflagellates in culture. The growth rates of diatoms are substantially greater than those of dinoflagellates and it is appropriate to use different parameters for these 2 groups. Banse (1982) presented equations for diatoms and dinoflagellates which related specific growth rate, $\mu_{m}\left(d^{-1}\right)$, with cell volume $\left(\mu \mathrm{m}^{3}\right)$ or cell carbon (pg C). The equations we have used are:

Diatoms:

$\log _{10} \mu_{m}=0.48-0.13\left(\log _{10}\right.$ cell carbon)

Dinoflagellates:

$\log _{10} \mu_{m}=0.14-0.15\left(\log _{10}\right.$ cell carbon $)$

These parameters were obtained by Banse for growth rates determined in culture at $20^{\circ} \mathrm{C}$ and continuous illumination. We have assumed that phytoplankton growth rate has a $Q_{10}$ value of 2 and the value of $\mu_{m}, 20^{\circ} \mathrm{C}$ for each species was adjusted to the ambient temperature at the time of sampling.

Production of each species was calculated by assuming exponential growth. The temperature-adjusted value of $\mu_{m}$ was applied to the biomass (in carbon) of each species in a sample to calculate the new biomass that would be produced in $1 \mathrm{~d}$ of growth. The difference between these 2 estimates of biomass is the potential productivity ( $\mathrm{mg} \mathrm{C} \mathrm{m} \mathrm{m}^{-3} \mathrm{~d}^{-1}$ ), that is, the increase in phytoplankton biomass that would occur under optimum growth conditions.

\section{RESULTS}

\section{Depth of optimum phytoplankton production}

Phytoplankton production is limited by a number of factors, including irradiance and nutrient availability. The hypothesis that we wish to test is that productivity of individual cells is a function of their cell size and that the total productivity of natural assemblages is also a function of the size of the phytoplankton that comprise that assemblage. Therefore, to test the hypothesis, it is important that comparisons are made between populations which are growing under optimum conditions. This is difficult to confirm with natural populations.

Fig. 1 shows 2 common depth profiles of ${ }^{14} \mathrm{C}$ fixation; Fig. 1 a shows the results of a $24 \mathrm{~h}$ in situ incubation at

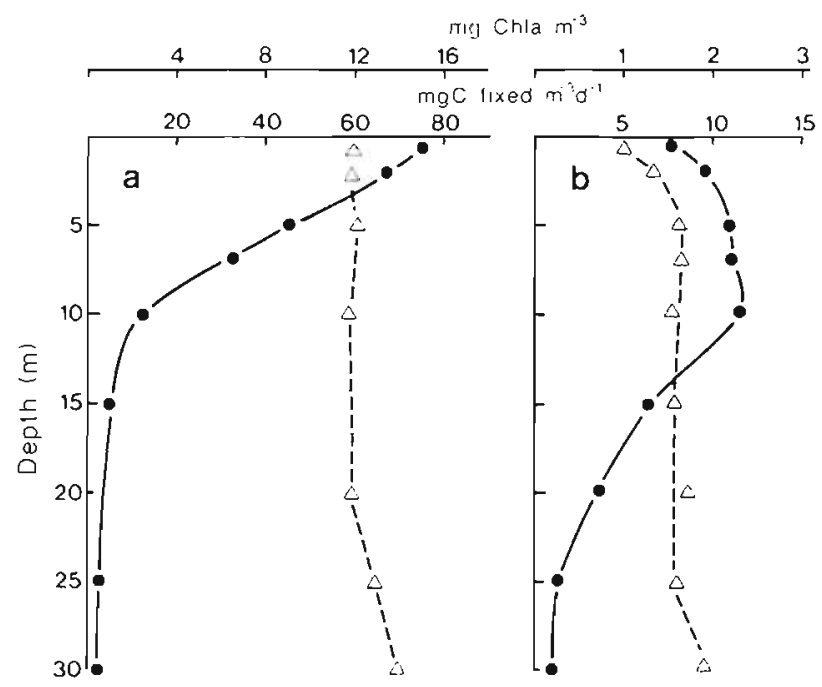

Fig. 1. Vertical profiles of chlorophyll a concentration $(\Delta)$ and in situ ${ }^{14} \mathrm{C}$ fixation rate $(\bullet)$ of phyloplankton retained by $5 \mu \mathrm{m}$ pore-size Nuclepore filters on (a) $21 \mathrm{Apr} 1984$ and (b) 23 May 1986

the time of a spring diatom bloom. Chlorophyll a concentrations were homogeneous within the surface $30 \mathrm{~m}$ but the production profile suggests considerable selfshading of the population. Cells taken from a depth of $10 \mathrm{~m}$ experience a very different light regime from those at $1 \mathrm{~m}$ and were clearly photosynthesizing at a much reduced rate. Vertical mixing of phytoplankton within the surface mixed layer would result in individual phytoplankton cells experiencing extremes of irradiance and it is impossible to determine what might be the 'optimum' growth rate of this population. In contrast, data obtained in May 1986 (Fig. 1b) show that ${ }^{14} \mathrm{C}$ fixation in the surface $10 \mathrm{~m}$ is approximately constant; there is some photoinhibition of the sample at the surface, but generally the rate of photosynthesis and the chlorophyll a content of the assemblage is constant between 5 and $10 \mathrm{~m}$. It is known that phytoplankton growth maximizes at lower irradiances than photosynthesis (Myers 1946). Therefore, we assume that phytoplankton cells at 5 to $10 \mathrm{~m}$ depth are growing at their optimum rate. In this paper, data from production profiles like Fig. $1 \mathrm{~b}$ are used to test the hypothesis of size dependence of ${ }^{14} \mathrm{C}$ rate by natural assemblages. 


\section{Relationship between phytoplankton biomass and ${ }^{14} \mathrm{C}$} fixation rate

Samples taken from 5 or $10 \mathrm{~m}$ on 26 occasions between 1982 and 1986 were analysed for species composition and cell counts; the carbon content of each species in the assemblage was estimated and summed to give the carbon content of the complete assemblage. Fig. 2 shows the results of a regression analysis of these

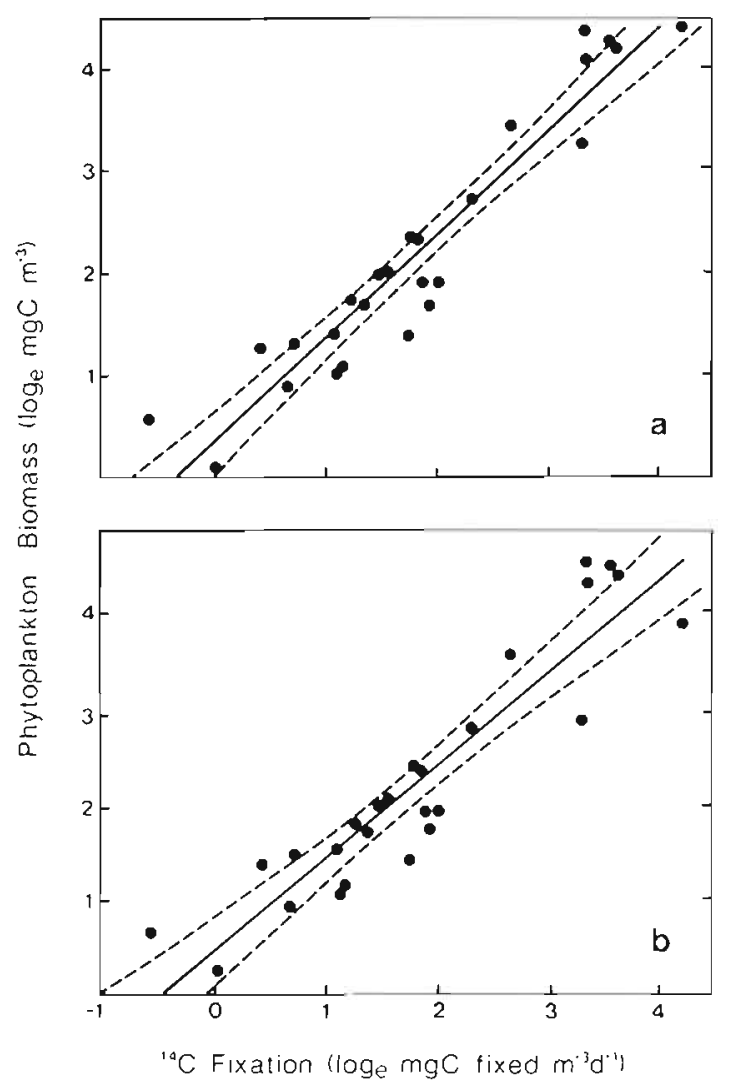

Fig. 2. Linear regression of $\log _{e}{ }^{14} \mathrm{C}$ fixation rate of phytoplankton retained by $5 \mu \mathrm{m}$ pore-size Nuclepore filters and $\log _{e}$ phytoplankton biomass determined from cell volume measurements using (a) Method 1 and (b) Method 2 algorithms. $n=$

$26, \ldots)$ approximate $95 \%$ confidence funnels

data against the $24 \mathrm{~h}{ }^{14} \mathrm{C}$ fixation rate for phytoplankton $>5 \mu \mathrm{m}$, determined in situ at the depth from which phytoplankton samples were taken. Fig. 2a shows the results obtained using Method 1 (Eqs. 2 and 3) and Fig. $2 b$ with Method 2 (Eqs. 4 and 5). In both cases, there was a strong correlation between ${ }^{14} \mathrm{C}$ fixation rate and the estimated phytoplankton biomass. The regression of the Method 1 estimate with ${ }^{14} \mathrm{C}$ rate (Fig. 2a) explained $90.3 \%$ of the total variability (F-ratio = $223.5 ; \mathrm{df}=24.1 ; p \leqq 0.001 \mathrm{j}$. The regression of Method 2 explained $85.2 \%$ of the total variability ( $F$-ratio $=$ $138.6 ; \mathrm{df}=24,1 ; p \leqq 0.001)$; both results are highly significant. The major difference between Methods 1 and 2 is apparent when the assemblages are dominated by diatoms. The equation of Strathmann (1967) for diatoms (Eq. 2) results in an estimate of cell carbon which is 1.5 times that obtained with the Taguchi parameters (Eq. 4).

\section{Productivity estimated from cell size}

This analysis demonstrates that the rate of photosynthetic fixation of carbon is clearly dependent on the biomass of phytoplankton present. However, in order to use a measure of phytoplankton biomass (with dimensions $\left[\mathrm{M} \mathrm{L}^{-3}\right]$ ), to predict a rate of growth (with dimensions $\left.\left[\mathrm{M} \mathrm{L}^{-3} \mathrm{~T}^{-1}\right]\right)$ it is necessary to introduce the dimension $\left[\mathrm{T}^{-1}\right]$. The constant (a) in the allometric Eq. (1) has the dimension $\left[\mathrm{T}^{-1}\right]$ (Platt 1985), constant (b) being dimensionless. We have applied the model (Eqs. 6 and 7) of Banse (1982) to the estimated carbon content of the individual species in order to calculate growth rate from phytoplankton biomass. Two equations are necessary because the specific growth of diatoms appears to be considerably greater than that of dinoflagellates. Eq. (7), which Banse derived for dinoflagellates only, was applied to all phytoplankton except diatoms. The increase in biomass of each species over the period of $1 \mathrm{~d}$ is assumed to be a measure of potential phytoplankton productivity and the sum for all species is assumed to be the productivity of the total assemblage.

Fig. 3 shows the results of a regression of ${ }^{14} \mathrm{C}$ fixation rate against the estimated potential productivity of the phytoplankton assemblage. In the case of both Methods 1 and 2, the regression is improved over that using biomass data. The regression of the Method 1 estimate with ${ }^{14} \mathrm{C}$ rate (Fig. $3 a$ ) explained $92.9 \%$ of the total variability $(F$-ratio $=312.2 ; \mathrm{df}=24.1 ; p \leqq 0.001)$. The regression of Method 2 explained $92.0 \%$ of the total variability $(F$-ratio $=276.2 ; \mathrm{df}=24,1 ; p \leqq 0.001)$

\section{Errors involved in estimating productivity from size}

The procedure to estimate the potential productivity of phytoplankton from the cell size involves 8 different calculations. These procedures have associated errors which, if cumulative, may render the estimate meaningless. The total errors involved in the procedure are calculated from the $95^{\circ}$ io confidence prediction limits An inverse regression analysis (Draper \& Smith 1981) for the Method 1 case is shown in Fig. 4; the curve fitted by linear regression of $\log _{e}{ }^{14} \mathrm{C}$ estimate against $\log _{e}$ of the estimate of productivity obtained from size was inverted and detransformed. As an example, with 


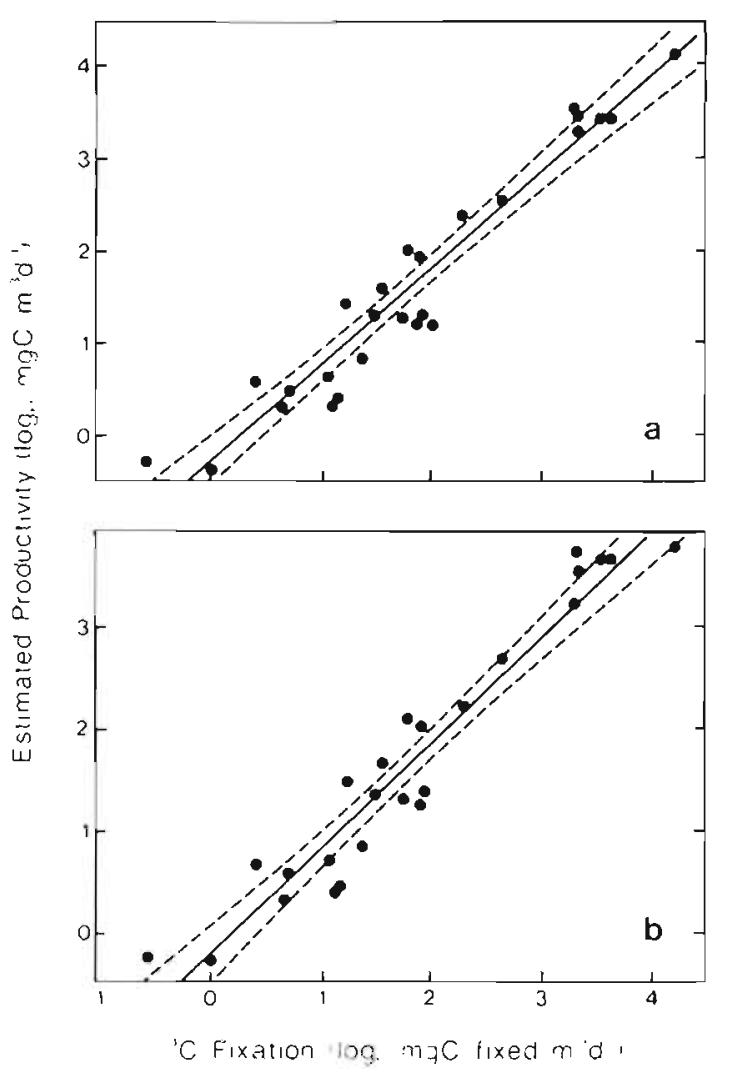

Fig. 3. Linear regression analysis of $\log _{e}$ phytoplankton productivity of cells $>5 \mu \mathrm{m}$, estimated from the allometric model and $\log _{e}{ }^{14} \mathrm{C}$ fixation rate of $>5 \mu \mathrm{m}$ phytoplankton: allometric model applied to biomass estimated with (a) Method 1 algorithms and (b) Method 2 algorithms. $n=26$; ( - -) $95 \%$ confidence funnels a value of productivity of $30 \mathrm{mgC} \mathrm{m}^{-3} \mathrm{~d}^{-1}$, the model estimates ${ }^{14} \mathrm{C}$ productivity to be $30.1 \mathrm{mgC} \mathrm{m}^{-3} \mathrm{~d}^{-1}$; from the prediction limits in Fig. 4 , we can be $95 \%$ certain that the true value of ${ }^{14} \mathrm{C}$ productivity would lie between 15 and $61 \mathrm{mgC} \mathrm{m}^{-3} \mathrm{~d}^{-1}$.

\section{DISCUSSION}

Despite the time-consuming procedures described in this paper the method offers significant increases in precision over other methods currently used. Phytoplankton biomass is frequently estimated from chlorophyll a concentration. However, the chlorophyll a content of algal cells is variable, the number and size of photosynthetic units depending on factors such as light history and nutrient availability (Prézelin 1981). Chlorophyll a might not be expected to be a particularly good estimator of phytoplankton biomass but, since chlorophyll $a$ is the primary pigment involved in photosynthesis, a strong correlation might be expected with ${ }^{14} \mathrm{C}$ fixation rate. Linear regression analysis of $\log _{e}$ ${ }^{14} \mathrm{C}$ fixation rate for the data examined in this paper and $\log _{e}$ chlorophyll a concentration explains only $58.9 \%$ of the total variability ( $F$-ratio $=34.5 ;$ df $=24,1 ; p$ $\leqq 0.001)$. Therefore, an estimate of biomass obtained by either Method $1\left(r^{2}=90.3 \%\right)$ or Method $2\left(r^{2}=85.2 \%\right)$ is a better predictor of ${ }^{14} \mathrm{C}$ activity than is chlorophyll a concentration. Other workers have found significant relationships between ${ }^{19} \mathrm{C}$ productivity estimates and biomass. Smayda (1965) found that cell volume explained $36 \%$ of the variance in ${ }^{14} \mathrm{C}$ productivity of
Fig. 4. Reverse regression analysis of ${ }^{24} \mathrm{C}$ fixaLion rate and allometric productivity estimate for Method 1. (- - $) 95 \%$ prediction funnels; (….) 1:1 ratio of the parameters: (-) range of ${ }^{14} \mathrm{C}$ productivity values within which the true ${ }^{19} \mathrm{C}$ value would lie if the allometric model estimated a value of $30 \mathrm{mgC} \mathrm{m}^{-3} \mathrm{~d}^{-1}$

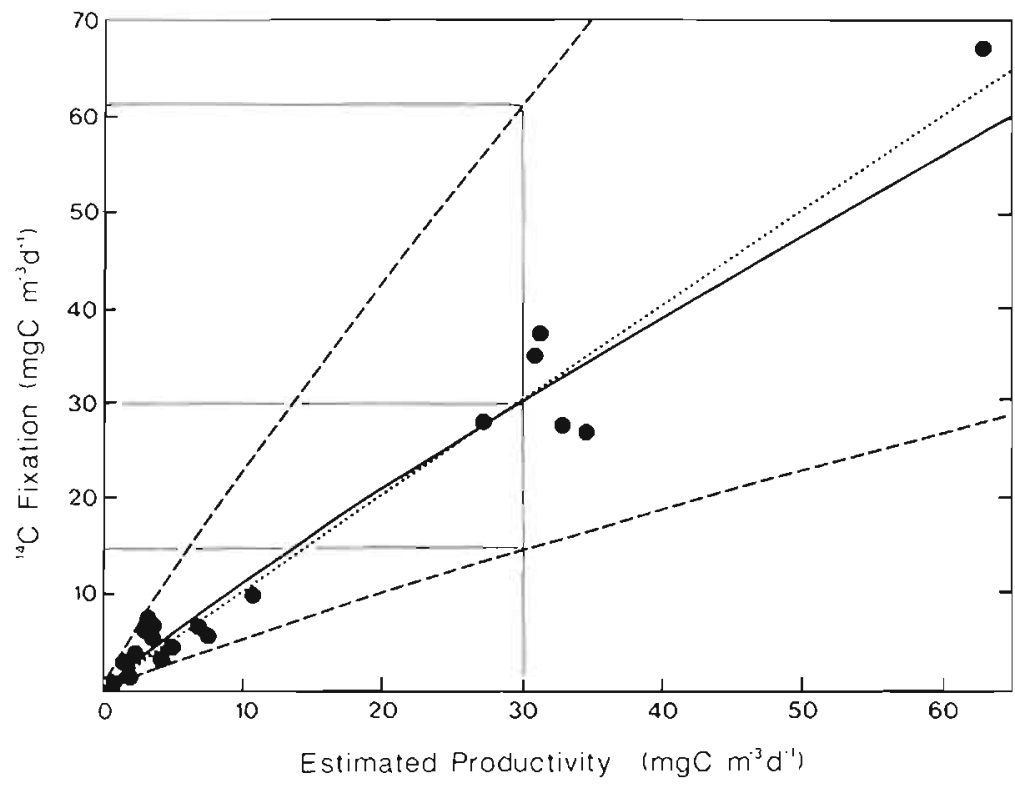


diatoms in the upwelling of the Gulf of Panama; the $r^{2}$ value increased to $42 \%$ if cell surface area, rather than cell volume was considered. Therefore, for certain studies, the increase in precision would justify the use of these time-consuming procedures to estimate phytoplankton biomass, in preference to chlorophyll a concentration.

In this paper, we have attempted to extend the use of phytoplarkton biomass. By applying an allometric model which introduces the dimension $\left[\mathrm{T}^{-1} \mid\right.$, we have shown that it is possible to use cell size to estimate the potential production of natural phytoplankton assemblages growing under optimum conditions. The results are statistically valid; an estimate based on Method 1 explains $92.9 \%$ of the variability in ${ }^{14} \mathrm{C}$ productivity data and Method 2 explains $92.0 \%$ of the variance.

However, a large number of potential errors are involved in this procedure. The errors involved in counting phytoplankton are well known (Lund et al. 1958) as are the errors of approximating the shape of phytoplankton cells to simple geometric forms (Bellinger 1974). We have done all our analysis on preserved samples and cell shrinkage as well as nonpreservation of delicate forms are potential problems. We have also taken one measurement to be representative of all of the individuals of one species and have not attempted to measure individuals from each sample. This is an over-simplification because cell volume increases during the cell cycle before cell division. Cell morphology may also change as a result of environmental conditions and we have described the elongation of Skeletonema costatum as a result of nutrient depletion in a marine mesocosm (Joint et al. 1987).

In addition to these potential errors in estimating phytoplankton biomass, there are uncertainties in the allometric coefficients derived by Banse (1982). The constant (a) has the dimension time $\left[\mathrm{T}^{-1}\right.$ ]; Platt (1985) considered that this scale coefficient was more critical to deductions about ecological properties than the exponent (b). It is therefore crucial that these constants are derived as accurately as possible. However, Banse (1982) was able to obtained only a limited number of data points from literature values, (10 for the diatom equation with an $r^{2}$ value of $70 \%$ and only 6 for the dinoflagellates, $x^{2}$ of $73 \%$ ). The data of Blasco et al. (1982) support the value of exponent determined by Banse for diatoms; Blasco et al. found a value of exponent of -0.1414 with 56 determinations of phytoplankton division rate and cell carbon content (but derived at $18^{\circ} \mathrm{C}$ ); this compares with -0.13 derived by Banse). However, other data are required to confirm the value of (a) derived by Banse (1982). It is worth noting that there is a very low mass dependence in the equations of Banse (1982); for diatoms, the exponent (b) is -0.13 and for dinoflagellates the value is -0.15 . This con- trasts with the value of -0.28 that Fenchel (1974) found for heterotrophic microbes. Therefore, the growth of phytoplankton does not appear to be as strongly dependent on body size as in other microbes.

${ }^{14} \mathrm{C}$ productivity estimates have been used throughout this paper. In doing so, we accept that ${ }^{14} \mathrm{C}$ estimates may not give the true rate of productivity but, since they are the mostly widely accepted method of determining productivity, they are the benchmark against which to compare the allometric estimate. We have shown close correspondence between the allometric and ${ }^{14} \mathrm{C}$ estimates of productivity, at the depth in the water column where optimum growth conditions apply. We have also attempled to indicate in Fig. 4 the magnitude of error that would be involved in applying this allometric model to natural populations. Whilst the range within the $95 \%$ prediction limits appears large, it may be no larger than that involved in ${ }^{14} \mathrm{C}$ productivity estimations; errors in ${ }^{1 /} \mathrm{C}$ productivity methods are rarely quoted but, given claims that the method may underestimate production by an order of magnitude or more (Sieburth 1977. Gieskes et al. 1979), the prediction limits of Fig. 4 seem acceptable. Precision may be improved by adopting more complex algorithms to calculate cell volume from cell dimension. Smayda (1978) suggests that as many as 11 linear measurements are required to determine the volume of certain dinoflagellates but we have used only 2 measurements.

The final caveat concerns extrapolation from the algorithms of Banse (1982) to the natural environment. The data that Banse used were obtained with cultures of algae growing under continuous illumination. We have not attempted to correct for day length in these calculations because most of the data from the Celtic Sea were obtained in summer. Cuhel et al. (1984) found that the exponential doubling time of Dunaliella tertiolecta under continuous illumination was not significantly different from that under a 16:8 h light:dark cycle. We have assumed that the same will be true for natural phytoplankton populations in the Celtic Sea and these are the data presented in Figs. 3 and 4 . If the data are adjusted for day length, there is no difference in the statistical significance of the relationship between the allometric model and ${ }^{14} \mathrm{C}$ estimates, but the predicted production is only $70 \%$ of that in Fig. 4. Since we do not know the absolute value for the production of natural phytoplankton assemblages, either estimation is justifiable.

Lastly, we wish to suggest that the allometric model can be used to estimate the productivity of the different phytoplankton species within a natural assemblage. Fig. 5a shows the productivity of phytoplankton $>5 \mu \mathrm{m}$ on 4 successive days at Stn CS2 in the Celtic Sea as estimated by the ${ }^{14} \mathrm{C}$ and allometric methods. Both methods give very similar results. The hydrographic 


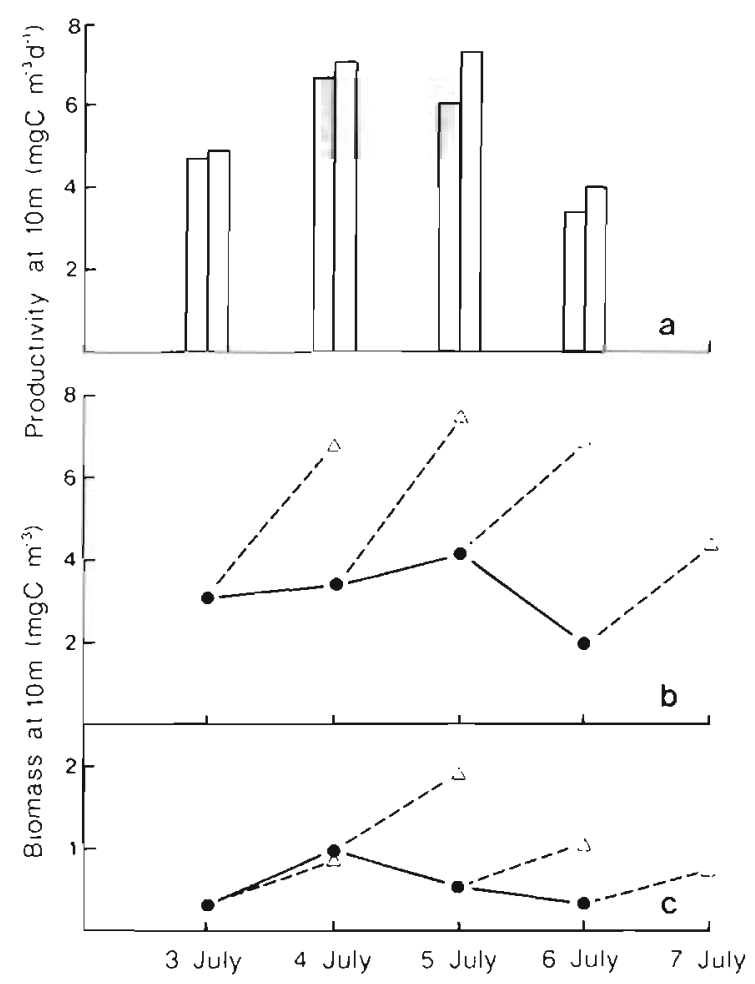

Fig. 5. (a) In situ ${ }^{19} \mathrm{C}$ fixation rate (shaded bars) of $>5 \mu \mathrm{m}$ phytoplankton and productivity of the same size fraction (open bars) on 4 consecutive days at Stn CS2 in the Celtic Sea (b) Biomass ( $\bullet$ ) of an unidentified flagellate estimated from cell volume by Method 1 , and biomass ( $\therefore$ ) predicted by the allometric model for the following day; (- -) productivity estimated by the allometric model. (c) Biomass of Heterocapsa sp. ( ) estimated from cell volume by Method 1, and biomass (ه) for the following day predicted by the allometric model: (- - ) estimated productivity of Heterocapsa

conditions at this time were particularly favourable for considering time series data. A secondary thermocline was present at $15 \mathrm{~m}$ (Joint \& Pomroy 1986) and so we know that phytoplankton cells in the surface water could not be mixed below the depth at which optimum growth occurred. Although we did not design a 'patch' study, in situ incubations were done using a freefloating incubation system (Joint \& Pomroy 1983) and this acted to mark the movements of a patch of water from day to day. We believe that there was minimal dispersion of the phytoplankton assemblage from 3 July until 6 July and that we are justified in assuming that we were sampling the same phytoplankton assemblage.

The allometric model sums the estimated production of all the phytoplankton species in a sample to give an estimate of assemblage productivity. Given the strong relationship between this estimate of assemblage productivity and that derived from ${ }^{14} \mathrm{C}$ estimates, and given the comparable results of the 2 methods for $4 \mathrm{~d}$ in July 1985 (Fig. 5a), we assume that the productivity estimates for all the individual species that make up the assemblage total are correct. Therefore, unlike the ${ }^{14} \mathrm{C}$ method which can only estimate a median value for the productivity of all of the algal cells present, we suggest that the allometric method can estimate the productivity of separate species.

Fig. 5 also shows the biomass of 2 species, an unidentified flagellate and Heterocapsa sp. The allometric productivity model indicates the biomass that would be expected $1 \mathrm{~d}$ later under optimum growth conditions. In the case of Heterocapsa sp. (Fig. 5c) there was good agreement between the actual biomass and the estimated biomass on 4 July. On all other days, and on all occasions for the flagellate, the estimated biomass was higher than the actual biomass; this difference between the 2 values is an estimate of the loss of phytoplankton cells by grazing and/or sedimentation. It is significant that we can show differences between species and that there was apparently little grazing on Heterocapsa between 3 and 4 July, but significant losses on subsequent days.

Allometric models appear to offer considerable potential as methods to estimate the productivity of phytoplankton under optimum growth conditions. The method also appears to offer a unique opportunity to estimate the productivity of individual species in a natural assemblage, which does not involve manipulation of the sample or incubation procedures and totally circumvents the problems associated with enclosing natural populations within bottles. We hope that this paper will lead to the testing of allometric models on data from other ecosystems.

Acknowledgement. We thank Martin Carr for writing the computer programmes which enabled us to process the data. This work formed part of the Shelf-Sea Ecology Programme of the Institute for Marine Environmental Research, a component of the UK Natural Environment Research Council; the Institute for Marine Environmental Research has now been amalgamated with the Plymouth Laboratory of the Marine Biological Association of the United Kingdom to form the NERC Plymoutb Marine Laboratory.

\section{LITERATURE CITED}

Banse, K. (1976). Rates of growth, respiration and photosynthesis of unicellular algae as related to cell size - a review. J. Phycol. 12: 135-140

Banse, K. (1982). Cell volumes, maximal growth rates of unicellular algae and ciliates and the role of ciliates in the marine pelagial. Limnol. Oceanogr. 27: 1059-1071

Bellinger, E. G. (1974). A note on the use of algal sizes in estimates of population standing crops. Br. phycol. J. 9: $157-161$

Bender, M., Grande, K., Johnson, K., Marra, J., Williams, P. J. LeB, Sieburth, J., Pilson, M., Langdon, C., Hitchcock, G., Orchardo, J., Hunt, C., Donaghay, P. (1987). A comparison of four methods for determing planktonic community production. Limnol. Oceanogr. 32: 1085-1098 
Blasco, D., Packard, T T., Garfield, P. C. (1982). Size dependence of growth rate, respiratory electron transport system activity, and chemical composition in marine diatoms in the laboratory. J. Phycol. 18: 58-63

Cuhel, R. L., Ortner, P. B., Lean, D. R. S. (1984). Night synthesis of protein by algae. Limnol. Oceanogr. 29: 731-744

Davies, J. M., Williams, P. J. LeB. (1984). Verification of ${ }^{14} \mathrm{C}$ and $\mathrm{O}_{2}$ derived primary organic production measurements using an enclosed ecosystem. J. Plankton. Res. 6: 457-474

Draper, N. R., Smith, H. (1981). Applied regression analysis, 2nd edn. John Wiley, New York

Eppley, R. W., Reid, F. M. H., Strickland, J. D. H. (1970). Estimates of phyloplankton crop size, growth rate, and primary production. Bull. Scripps Inst. Oceanogr. 17: $33-42$

Fenchel, $T$ (1974). Intrinsic rate of natural increase: the relationship with body size. Oecologia (Berl.) 14: 317-326

Gieskes, W W. C., Kraay, G. W. Baars, M. A. (1979). Current ${ }^{14} \mathrm{C}$ methods for measuring primary production: gross underestimates in oceanic waters. Neth. J. Sea Res. 13: $58-78$

Hasle, G. R. (1978). The inverted-microscope method. In: Soumia, A. (ed.) Phytoplankton manual. UNESCO. Paris, p. $88-96$

Joint, 1. R. (1986). Physiological ecology of picoplankton in various oceanographic provinces. In: Platt, T., Li, W. K. W (eds.) Photosynthetic picoplankton. Can. Bull. Fish. Aquat. Sci. 214: 287-309

Joint, I. R., Pomroy, A. J. (1983). Production of picoplankton and small nanoplankton in the Celtic Sea. Mar. Biol. 77 : $19-27$

Joint, I. R., Pomroy, A. J. (1986). Photosynthetic characteristics of nanoplankton and picoplankton from the surface mixed layer. Mar. Biol. 92: 465-474

Joint, I. R., Owens, N. J. P., Pomroy, A. J. (1986). Seasonal production of photosynthetic picoplankton and nanoplankton in the Celtic Sea. Mar. Ecol. Prog. Ser 28: $251-258$

Joint, I. R., Pomroy, A. J., Robinson, G. A., Morris, R. J., McCartney, M. J. (1987). Morphological changes in Skeletonema costatum (Bacillariophyceae) during a spring bloom in a marine ecosystem enclosure. Br. phycol. J. 22: $119-124$

Lund, J. W. G., Kipling, C., Le Cren, E. D. (1958). The inverted microscope method of estimating algal numbers and the statistical basis of estimating by counting. Hydrobiologia 11: $143-170$

Myers, J. (1946). Culture conditions and the development of the photosymthetic mechanism III. Influence of light intensity on cellular characteristics of Chlorella. J. gen. Physiol. 29: 419-427

Peters, R. H. (1983). The ecological implications of body size. Cambridge University Press, Cambridge.

Peterson, B. J. (1980). Aquatic primary productivity and the
${ }^{14} \mathrm{C}-\mathrm{CO}_{2}$ method; a history of the productivity problem Ann. Rev. Ecol Syst. 11: 359-385

Platt. T (1985). Structure of the marine ecosystem: its allometric basis. In. Ulanowicz, R. E., Platt, T (eds.) Ecosystem theory for biological oceanography. Can. Bull. Fish. Aquat. Sci. 213: 55-64

Platt, T., Denman, K. (1977). Organisation in the pelagic ecosystem. Helgoländer wiss. Meersunters. 30: 575-581

Platt, T., Denman, K. L. (1978). The structure of the pelagic marine ecosystem. Rapp. P.-v. Réun. Cons. int. Explor. Mer 173: 60-65

Porter, F. G., Feig, Y. S. (1980). The use of DAPI for identifying and counting aquatic microflora. Limnol. Oceanogr. 25 943-948

Prézelin, B. B. (1981). Light reactions in photosynthesis. In: Platt. T. (ed.) Physiological bases of phytoplankton ecology. Can. Bull. Fish. Aquat. Sci. 210: 1-43

Schwinghamer, P. (1981). Characteristic size distributions of integral benthic communities. Can. J. Fish. Aquat. Sci. 38 $1255-1263$

Sieburth, J. McN. (1977). International Helgoland Symposium: conveners report on the informal session on biomass and productivity of microorganisms in pianktonic ecosystems. Helgoländer wiss. Meeresunters. 30: 697-704

Smayda, T J. (1965). A quantitative analysis of the phytoplankton of the Gulf of Panama. II. On the relationship between ${ }^{14} \mathrm{C}$ assimilation and the diatom standing crop Bull. inter-Am. trop. Tuna Commn. 9: 465-531

Smayda, T J. (1978). From phytoplankters to biomass. In: Sournia, A. (ed.) Phytoplankton manual. UNESCO. Paris p. $273-279$

Steeman Nielsen, E. (1951). Measurement of the production of organic matter in the sea by means of carbon-14. Nature, Lond. 167: 684-685

Strathmann, R. R. (1967). Estimating the organic carbon content of phytoplankton from cell volume or plasma volume. Limnol. Oceanogr. 12: 411-4,18

Taguchi, S. (1976). Relationship between photosynthesis and cell size of marine diatoms. J. Phycol. 12: 185-189

Vézina, A. F. (1986) Body size and mass flow in freshwater plankton: models and tests. J. Plankton. Res. 8: 939-956

Warwick, R. M. (1984). Species size distributions in marine benthic communities. Oecologia (Berl.) 61: 32-41

Warwick, R. M., Collins, N. R., Gee, J. M., George, C. L. (1986). Species size distributions of benthic and pelagic Metazoa: evidence for interaction? Mar. Ecol. Prog. Ser. 34: $63-68$

Warwick, R. M., Joint, I. R. (1987). The size distribution of organisms in the Celtic Sea: from bacteria to Metazoa. Oceologia (Berl.) 73: 185-191

Williams, P. J. LeB, Heinemann, K. R., Marra, J., Purdie, D. A (1983). Comparison of ${ }^{14} \mathrm{C}$ and $\mathrm{O}_{2}$ measurements of phytoplankton production in oligotrophic waters. Nature, Lond. 305: 49-50 